\title{
ANALYSIS OF THE COFFEE PEEL APPLICATION OVER THE SOIL-CEMENT BRICKS PROPERTIES
}

\author{
Eliziane Denize de Castro, Luciana Silva Villela², Lourival Marin Mendes², \\ Rafael Farinassi Mendes ${ }^{4}$, André Geraldo Cornélio Ribeiro ${ }^{5}$, José Benedito Guimarães Junior ${ }^{6}$, \\ Giovanni Francisco Rabelo ${ }^{7}$
}

(Received: August 23, 2018; accepted: February 11, 2019)

\begin{abstract}
The development of materials that use less polluting manufacturing techniques and can be manufactured from agricultural and/or industrial waste is an increasingly explored field of research. The objective of this work was to study the effects of the coffee peel particles (Coffea arabica L.) incorporation in partial replacement of cement, on the physical, mechanical and thermal properties of bricks, at different ages. For this purpose, soil corrected with sand, Portland cement type CP II F-32 and coffee peel particles were used. After the initial percentage of cement in the mixture was defined as $10 \%$, coffee peels were added in relation to cement, equal to $5 \%, 10 \%, 15 \%$ and $20 \%$. The bricks were submitted to simple compression tests, at the ages of 14, 28 and 56 days, thermal insulation at 28 days. The increase in peel content caused increases in water absorption, and reduction of compressive strength and apparent specific dry mass. The interaction between the shell content and the age of the specimens was significant only for the variable resistance to compression. The thermal conductivity found for the material showed its insulating potential, with values below those determined for ceramic bricks. In general, it can be concluded that the material produced did not fit in the normative requirements for soil-cement bricks, however, the mechanical characteristics found in there, indicate the possibility of use in rustic constructions, such as those ones made with adobe bricks.
\end{abstract}

Index terms: Compressive strength, durability, thermal properties, vegetable particles.

\section{ANÁLISE DA APLICAÇÃo DE CASCA DE CAFÉ NAS PROPRIEDADES DE TIJOLOS DE SOLO-CIMENTO}

\begin{abstract}
RESUMO: O desenvolvimento de materiais que utilizem técnicas de fabricação menos poluidoras e que possam ser fabricados a partir de rejeitos agrícolas e/ou industriais é um campo de pesquisa cada vez mais explorado. O presente trabalho teve como objetivo estudar os efeitos da incorporação de partículas de casca de café (Coffea arabica L.), em substituição parcial ao cimento, sobre as propriedades físicas, mecânicas e térmicas de tijolos em diferentes idades. Para tanto, foi utilizado solo corrigido com areia, cimento Portland do tipo CP II F-32 e partículas de casca de café. Definido o percentual inicial de cimento na mistura em $10 \%$, foram inseridos percentuais de casca de café, em relação ao cimento, iguais a 5\%, 10\%, 15\% e $20 \%$. Os tijolos foram submetidos aos ensaios de compressão simples, nas idades de 14, 28 e 56 dias, isolamento térmico, aos 28 dias. O aumento no teor de casca provocou acréscimos na absorção de água e redução da resistência à compressão e massa específica aparente seca. A interação entre o teor de casca e a idade dos corpos de prova foi significativa apenas para a variável resistência à compressão. A condutividade térmica encontrada para o material evidenciou seu potencial isolante, com valores abaixo dos determinados para tijolos cerâmicos. De um modo geral, pode-se concluir que o material produzido não se enquadrou nas exigências normativas para tijolos de solo-cimento, entretanto, as características mecânicas encontradas, indicam a possibilidade de utilização em construções rústicas, como as realizadas com tijolos de adobe.
\end{abstract}

Termos para indexação: Resistência à compressão, durabilidade, propriedades térmicas, partículas vegetais.

\section{INTRODUCTION}

The development of the construction industry brings with it some adversities that contribute to the environmental degradation. In this context, we are increasingly seeking to manufacture materials by less polluting methods, as well as the use of waste, which, in days before, would be incorrectly discarded in nature.

Among the techniques considered sustainable, the use of materials produced from the use of raw earth, is again gaining its space, highlighting the use of soil-cement, which basically consists of mixing appropriate dosages of soil, cement and water. With the mixture, it is possible to manufacture bricks that are obtained from their pressing, which do not require burning and are therefore, considered environmentally friendly. In addition, soil-cement brick is an interesting alternative for housing construction, especially in developing countries (SEGANTINI; WADA, 2011; RODRIGUES; HOLANDA, 2015). Regarding the reuse of waste, in the last years, many researches have been developed

\footnotetext{
1,2,3Universidade Federal de Lavras/UFLA - Departamento de Ciências Florestais/DCF - Cx. P. 3037 - 37.200-000 - Lavras - MG eliziane.castro@yahoo.com.br, lucianavillela_3@hotmail.com, lourival@dcf.ufla.br

4,5,6,7Universidade Federal de Lavras/UFLA - Departamento de Engenharia/DEG - Cx P. 3037 - 37.200-000 - Lavras - MG rafael.mendes@deg.ufla.br, andreribeiro@deg.ufla.br, jose.guimaraes@deg.ufla.br, rabelo@deg.ufla.br
} 
around the world, from the combination of the most varied types of residues of industrial and agricultural origin, in the manufacture of soil and cement-soil bricks. In general, plant fibers and particles tend to reduce the bricks density, improve thermal insulation, and may increase the material ductility, as observed by some authors, such as Chaib et al. (2015), Sutas et al. (2012) and Zak et al. (2016).

Among the agricultural residues produced in Brazil, the coffee peel is prominent, mainly in the state of Minas Gerais, in particular, in the southern region of Minas Gerais, which implies in the exacerbated generation of this residue. Most of the time, this waste is disposed inappropriately in the environment, which can cause ecological imbalances.

The concern with the energetic efficiency of the constructions has considerably increased in the last years, considering that the majority of energy consumed comes from the residential buildings, with predominance of heating and cooling systems, which culminated with an effective increase in the adoption of air conditioners (DOUKAS et al., 2006).

The soil itself, as a construction material, has good thermal transmittance characteristics, considering the energy efficiency, in addition, the possibility of allying it to plant residues may result in an increase in the insulation capacity of the material developed, providing greater comfort for the occupants of the building, thus (ASHOUR et al., 2015).

In this context, the objective of this work was to evaluate the effects of the substitution of cement by coffee peels on the physical, mechanical and thermal properties of soil-cement bricks at different ages.

\section{MATERIAL AND METHODS}

\section{Soil characterization and coffee peels}

The coffee peel belonging to the Coffea arabica $L$. species was obtained in the city of Machado-MG, from the drying of the grains in mechanical dryers. The residues were immersed in a solution of hydrated lime CH III, concentrated at $5 \%$ for a period of 24 hours (SERRANO; CASTRO, 1985). Subsequently, the materials were washed and oven dried for a period of 48 hours at a temperature of $80{ }^{\circ} \mathrm{C}$. This procedure was necessary to avoid chemical incompatibility between the plant biomass and the mineral binder.
After drying, the vegetal materials were crushed and classified, using the residues that passed in the 40 -mesh sieve $(0.420 \mathrm{~mm}$ mesh opening) and were retained in the 60-mesh sieve (0.250 $\mathrm{mm}$ mesh opening), aiming at a better particles homogenization with the other mixture components. The characterization tests took place in the Experimental Unit of Wood Panels UEPAM of the Federal University of Lavras, as described in Table 1.

The soil, extracted in the campus of the Federal University of Lavras, was previously smashed, sieved and conditioned in a place free of the weather action. The characterization tests were carried out at the Geotechnics Laboratory at the Federal University of Lavras, as described in Table 1.

The basic density of the particles was determined using the Direct Volume Measurement by Graduated Cylinder method, with samples immersed in water in six replicates. After saturation, about $10 \mathrm{~g}$ per sample were weighed and placed in graduated beakers. The sample volume was given by the difference between the final volume and the initial volume. Afterwards, the samples were oven dried at $103 \pm 2{ }^{\circ} \mathrm{C}$ until reaching constant weight. The basic density is given by the quotient between the dry mass of the particle and the volume of the sample.

\section{Bricks production}

In the essays and in the tests, the bricks with particles of coffee peel, with four different proportions, in relation to dry mass, replacing the cement, besides a control treatment, free of particles, were evaluated, according to Table 2 . The amount of cement to be added to the mixture was defined, from the characterization of the soil to be used and its classification, according to the HRB (1961), as recommended in ET-35 published by ABCP (1986).

The bricks were produced in the Experimental Unit of Wood Panels - UEPAM of the Federal University of Lavras. After the components homogenization, the mixture was pressed by a manual press adaptation, within one hour, in maximum, according to ABCP (2000). The bricks obeyed the established dimensions, for Type II, according to the standard NBR 8491 (ABNT, 2012a). The cure occurred in the first seven days of age with wet cycles three times a day. After curing, the bricks were stored in a covered place until the test date. 
TABLE 1 - Characterization tests of soil and coffee peels.

\begin{tabular}{ccc} 
Type of material & Test & Standards \\
\hline \multirow{3}{*}{ Soil } & Granulometry & NBR 7181 (ABNT, 1984b) \\
& Specific grain mass & NBR 6508 (ABNT, 1984a) \\
& Liquidity and & NBR 6459 (ABNT, 2016b) \\
& Plasticity Limit & NBR 7180 (ABNT, 2016c) \\
& Humidity & NBR 6457 (ABNT, 2016a) \\
& Proctor Normal Compression & NBR 7182 (ABNT, 1986) \\
\hline \multirow{3}{*}{ Coffee peels } & Lignin content & NBR 7989 (ABNT, 2010a) \\
& Extraction content & NBR 14583 (ABNT, 2010b) \\
& Ashes & NBR 13999 (ABNT, 2003) \\
& Holocellulose & H (\%) $=100-$ Lignin - \% Total \\
\end{tabular}

TABLE 2 - Experimental Design

\begin{tabular}{cllll}
\hline Treatment & $\begin{array}{l}\text { Soil } \\
(\%)\end{array}$ & $\begin{array}{l}\text { Cement } \\
(\%)\end{array}$ & $\begin{array}{l}\text { Coffee peel } \\
(\%)\end{array}$ & $\begin{array}{l}\text { Peel /cement } \\
(\%)\end{array}$ \\
\hline T0 & 90 & 10 & 0 & 0 \\
T1 & 90 & 9.5 & 0.5 & 5 \\
T2 & 90 & 9.0 & 1.0 & 10 \\
T3 & 90 & 8.5 & 1.5 & 15 \\
T4 & 90 & 8.0 & 2.0 & 20 \\
\hline
\end{tabular}

\section{Bricks characterization}

The bricks produced were subjected to the described tests, to determine their properties, as shown in Table 3.

The bricks thermal properties were evaluated in three replicates of each treatment at the 28 days age. To determine the thermal conductivity, a chamber was used, composed of reconstituted wood panels and, for sealing, styrofoam plates of $15 \mathrm{~mm}$ thickness, model Fresh foil Premium aluminized blanket, consisting of five layers (aluminum / polyethylene / reinforcement / polyethylene / aluminum), with approximate reflection of $90 \%$ and aluminized adhesive tape. All treatments were evaluated using the same heat source, an incandescent lamp with controllable temperature and variable up to $90{ }^{\circ} \mathrm{C}$. The temperatures were recorded by thermocouples Data Collector, model
IM DC 100-01E, manufactured by Yokogawa. The samples were assayed alone, and the material was exposed at room temperature, around $50^{\circ} \mathrm{C}$. The heating rate was $1^{\circ} \mathrm{C} / \mathrm{min}$. and the test cycle for each treatment was approximately 3 hours. The thermal conductivity was calculated when the system reached a steady state of conduction of heat, from the temperatures obtained in the base and the top of the specimen and the heat flow (W/ $\mathrm{m}^{2}$ ) measured by means of a radiation-measuring device. The information obtained was used to calculate the properties established in the NBR 15220 (ABNT, 2005a).

The equations below were used to calculate the thermal conductivity (Equation 1), thermal resistance (Equation 2), thermal transmittance (Equation 3), thermal delay (Equation 4) and solar gain factor (Equation 5). 
TABLE 3 - Bricks characterization tests.

\begin{tabular}{cccc}
\hline Test & Procedure & Age (days) & $\begin{array}{c}\text { Bricks / } \\
\text { Treatment }\end{array}$ \\
\hline Dimensional analysis & NBR 8492 (ABNT, 2012b) & $14,28,56$ & 7 (total 105) \\
Compressive strength & NBR 8492 (ABNT, 2012b) & $14,28,56$ & 4 (total 60) \\
Water absorption & NBR 8492 (ABNT, 2012b) & $14,28,56$ & 3(total 45) \\
\hline
\end{tabular}

$$
\mathrm{K}=\frac{\mathrm{qk} / \mathrm{A}}{\mathrm{dT} / \mathrm{dx}}
$$$$
R=\frac{e}{h}
$$

$$
U=\frac{1}{R t}
$$

$$
\varphi=1.382 \times \mathrm{ex} \sqrt{\frac{\rho \times c}{3.6 \times e}}
$$

$$
\mathrm{FSo}=4 \mathrm{xU \times} \alpha
$$

Where $\mathrm{K}$ represents the thermal conductivity (W / $(\mathrm{mK}))$, qk is the heat flux (W), $\mathrm{A}$ is the area perpendicular to the heat flux (m), dT is temperature variation $\left({ }^{\circ} \mathrm{C}\right.$ or $\left.\mathrm{K}\right), \mathrm{dx}$ is the heat flux length $(\mathrm{m}), \mathrm{R}$ is the thermal resistance $\left(\mathrm{m}^{2} . \mathrm{K}\right.$ / W), $\mathrm{U}$ is thermal transmittance $\left.\left(\mathrm{m}^{2} \cdot \mathrm{K}\right) / \mathrm{W}\right), \varphi$ is the thermal delay, and is the thickness of the (m), $\rho$ is the apparent density of the material, $\mathrm{c}$ is the specific heat of the material, FSo is the solar factor in opaque elements $(\%), \alpha$ is solar radiation absorptivity - color function.

The experimental data were evaluated considering a completely randomized design, in a $5 \times 3$ factorial scheme (five percent cement replacement by coffee husk particles - $0,5,10$, 15 and $20 \%$, and three cure ages - 14, 28 and 56 days. The results were submitted to variance analysis and, when significant, the linear regression analysis was performed and, for the treatments differentiation, the cluster test Scott Knott (SCOTT; KNOTT, 1974) at the 5\% level of significance was done.

\section{RESULTS AND DISCUSSION}

\section{Soil characterization}

The results obtained from the soil characterization are shown in Table 4.

According to NBR 10833 (ABNT, 2012c), the maximum percentage of through-grains in the 200 -mesh sieve should be equal to $50 \%$. Thus, to use the chosen soil it was necessary to increase the grains percentage with diameters greater than $0.075 \mathrm{~mm}$, thus reducing the amount of fines. This correction was made by adding sand in proportions calculated as a function of the initial percentage of the grain in the soil. After correction, the soil presented a percentage of through-grains in the 200 -mesh sieve equal to $43.79 \%$, lower than the maximum allowed by standards, making its use possible in soil-cement mixtures.

According to studies developed by the Center for Research and Development (CEPED, 1999), the ideal sand percentages in the mixture should be between $45 \%$ and $90 \%$, the silt + clay content between 10 and $55 \%$ and a clay content less than $20 \%$. Considering these parameters, it is evident, when analyzing the results presented in Table 3, the success obtained in the applied granulometric correction.

In relation to the specific mass of the soil grains, a slight reduction is observed between the value reached for the natural soil and the value found for the corrected soil, which may be associated with the substitution of denser clay minerals for lighter minerals, since the clay quantity was quite reduced, in detriment of the addition of sand.

NBR 10833 (ABNT, 2012c) establishes that the value of the liquidity limit for soils for use in soil-cement mixtures is less than $45 \%$. According to the results found, the soil, in its natural condition, had a liquidity limit equal to $51 \%$, slightly above the standard allowed. 
TABLE 4 - Natural and corrected soil characteristics.

\begin{tabular}{ccc}
\hline Soil Characteristic & Natural soil & Corrected soil \\
\hline Boulder (\%) & 0 & 0 \\
Sand (\%) & 28.58 & 74.91 \\
Silt (\%) & 26.68 & 7.02 \\
Clay (\%) & 44.74 & 18.07 \\
\hline \% of material passing through \# 4 sieve $(4.8 \mathrm{~mm})$ & 100 & 100 \\
\% of the material passing through the \# 200 sieve $(0.075 \mathrm{~mm})$ & 86.09 & 43.79 \\
\hline Specific soil grains (g/cm $)$ & 2.75 & 2.55 \\
\hline Liquidity limit (\%) & 51 & 27 \\
Plasticity Limit (\%) & 40 & 25 \\
Plasticity Index (\%) & 11 & 2 \\
\hline
\end{tabular}

This situation can be explained by the high presence of fine particles in its composition, which ratifies the need of applied granulometric correction. According to the correction adopted, the value obtained for the liquidity limit was $27 \%$, within the limits of the standard.

NBR 10833 (ABNT, 2012c) does not establish limit values for the plasticity limit, only for the plasticity index, which should not exceed $18 \%$. From the data in Table 3, it can be observed that both the plasticity index for the natural soil and for the corrected soil are within the norm (IP $<18 \%$ ).

According to the characteristics showed, the soil used was classified as type A-4, the recommended percentage of cement, for this type of soil, is equal to $10 \%$ (ABCP, 1986).

Table 5 shows the values found for optimum moisture and maximum specific apparent dry mass as consequence of the compositions studied.

It can be inferred that the insertion of the coffee peel particles into the soil-cement mixture tends to reduce the specific apparent dry mass while increasing the optimum moisture. When comparing the treatments with $0 \%$ and $20 \%$ of coffee peel respectively, it was observed that there was a reduction of $10 \%$ in the maximum specific apparent dry mass and an increase equal to $9.78 \%$ in the optimum moisture of the mixture. One of the points that contribute to this conclusion is the difficulty found in compaction of the mixture for high coffee peel contents, which causes the volume of voids to increase in the compacted system (MILANI; FREIRE, 2006).

\section{Characterization of coffee peels particles}

Table 6 shows the results of the chemical analysis and basic density of the coffee peel particles before and after the applied treatment. It is noticed that there was significant variation, for the different chemical components evaluated, due to the application of the treatment in the particles of coffee peel.

The ash, lignin and extractives contents suffered considerable reduction of their values. It is observed a considerable reduction in the total extractive content, present in the in natura material, which tends to be beneficial, since the starches, sugars, phenols and other components present in the extractive content are mainly responsible for the inhibition of the cement hydration reaction, which directly influences the physical and mechanical properties of the material (WEATHERWAX; TARKOW, 1964; FRYBORT et al., 2008; IWAKIRI; PRATA, 2008).

The increase in the observed holocellulose content can be attributed to the reduction of the other components in proportional terms. Asasutjarit et al. (2007), when studying the chemical composition of green coconut fibers with different treatments also verified the increase in percentage terms of holocellulose.

Regarding density, the values found were compatible with other studies, such as that developed by Vale et al. (2007), which obtained densities equal to $0.166 \mathrm{~g} / \mathrm{cm}^{3}$ and $0.144 \mathrm{~g} / \mathrm{cm}^{3}$, for the dry and wet coffee peel of the variety (Coffea arabica L.). It is also observed that the density of the peel after treatment, grinding and sieving was much higher than that of the peel in natura. 
TABLE 5 - Values obtained for the specific apparent maximum dry mass and optimum humidity for the compositions adopted.

\begin{tabular}{cccccc}
\hline \multirow{2}{*}{$\begin{array}{c}\text { Coffee peel / } \\
\text { Cement }\end{array}$} & \multicolumn{3}{c}{ Composition } & & \\
\cline { 2 - 3 } & Corrected soil (\%) & Cement (\%) & Coffee peel (\%) & $\mathrm{W}_{\text {ot }}(\%)$ & $\gamma_{\text {dmáx }}\left(\mathrm{g} / \mathrm{cm}^{3}\right)$ \\
\hline $0 \%$ & $90 \%$ & $10 \%$ & $0 \%$ & $16.60 \%$ & 1.80 \\
$5 \%$ & $90 \%$ & $9.5 \%$ & $0.5 \%$ & $18.00 \%$ & 1.73 \\
$10 \%$ & $90 \%$ & $9.0 \%$ & $1 \%$ & $18.20 \%$ & 1.72 \\
$15 \%$ & $90 \%$ & $8.5 \%$ & $1.5 \%$ & $18.70 \%$ & 1.69 \\
$20 \%$ & $90 \%$ & $8.0 \%$ & $2.0 \%$ & $18.40 \%$ & 1.62 \\
\hline
\end{tabular}

Note: $\mathrm{W}_{\mathrm{ot}}:$ optimum humidity; $\gamma_{\mathrm{dmax}}:$ specific apparent maximum dry mass.

TABLE 6 - Results of chemical analysis and basic particle density.

\begin{tabular}{cccccc}
\hline Coffee peel & Ashes (\%) & $\begin{array}{c}\text { Lignin } \\
\mathbf{( \% )}\end{array}$ & Extracts (\%) & $\begin{array}{c}\text { Holocellulose } \\
\mathbf{( \% )}\end{array}$ & Density (g/cm $\mathbf{~})$ \\
\hline No treatment & $5.89 \pm 0.28 \mathrm{~A}$ & $50.70 \pm 0.39 \mathrm{~A}$ & $11.47 \pm 0.82 \mathrm{~A}$ & $31.93 \pm 0.53 \mathrm{~A}$ & $0.139 \pm 0.02 \mathrm{~A}$ \\
With treatment & $2.47 \pm 0.04 \mathrm{~B}$ & $24.30 \pm 2.08 \mathrm{~B}$ & $7.38 \pm 0.49 \mathrm{~B}$ & $65.85 \pm 1.63 \mathrm{~B}$ & $0.298 \pm 0.08 \mathrm{~B}$ \\
\hline
\end{tabular}

Note: Mean values followed by the same capital letter in the column belong to the same cluster by Scott-Knott test at $5 \%$ significance.

This situation occurred due to the increase of the specific surface and consequent reduction of the number of voids, which left the material less porous. Another hypothesis is the possible existence of lime residues, which can mask the results by increasing the density value, since the lime is much denser than the particle.

\section{Specific apparent dry mass and water absorption of bricks}

Based on the statistical analysis, it was verified that the factors age of evaluation and type of treatment were significant, for the apparent specific dry mass variable and water absorption, however the interaction between them was not significant. Figure 1 shows the average values obtained for the specific dry mass and bricks water absorption, as a function of the percentage of cement replacement per coffee peel used in each treatment.

It can be seen from the graph that the increase in the coffee peel content in the mixture causes the reduction in the specific dry mass of the brick, and in contrast, increases water absorption of the material. When comparing the values found for the control treatment and the treatment containing $20 \%$ of coffee peel, there was a decrease of $9.06 \%$ in the apparent specific dry mass and a $41.79 \%$ increase in water absorption. These results can be explained by the lack of interaction between the soil-cement system and peel and by the presence of chemical components, such as lignin, extractives, cellulose, hemicellulose, among others, present in the coffee peel. They tend to delay or even impede the cement hydration process, which promotes an increase in the volume of voids, leaving the material more porous, consequently lighter and with a greater capacity to absorb water, as the increase in the content of particles.

The sugars from lignin hydrolysis and hemicellulose solubilization are mainly responsible for the drop in temperature and consequent delay, in the process of cement hydration, according to some authors as Bilba, Arsene and Ouensanga (2007), Sudin and Swamy (2006) and Vaickelionis and Vaickelioniene (2006).

Zak et al. (2016), in their studies with mixtures of soil, cement, gypsum and flax and hemp fibers, also observed the decrease of the specific mass, from the introduction of vegetal matter. The authors attribute this effect to the low density of plant fibers and the need for higher water contents to achieve the ideal molding consistency.

When only the age factor of the test specimens was evaluated, it can be seen from Figure 2 that the means reached for the ages of 14, 28 and 56 days were statistically different from each other for the specific apparent dry mass variable. 


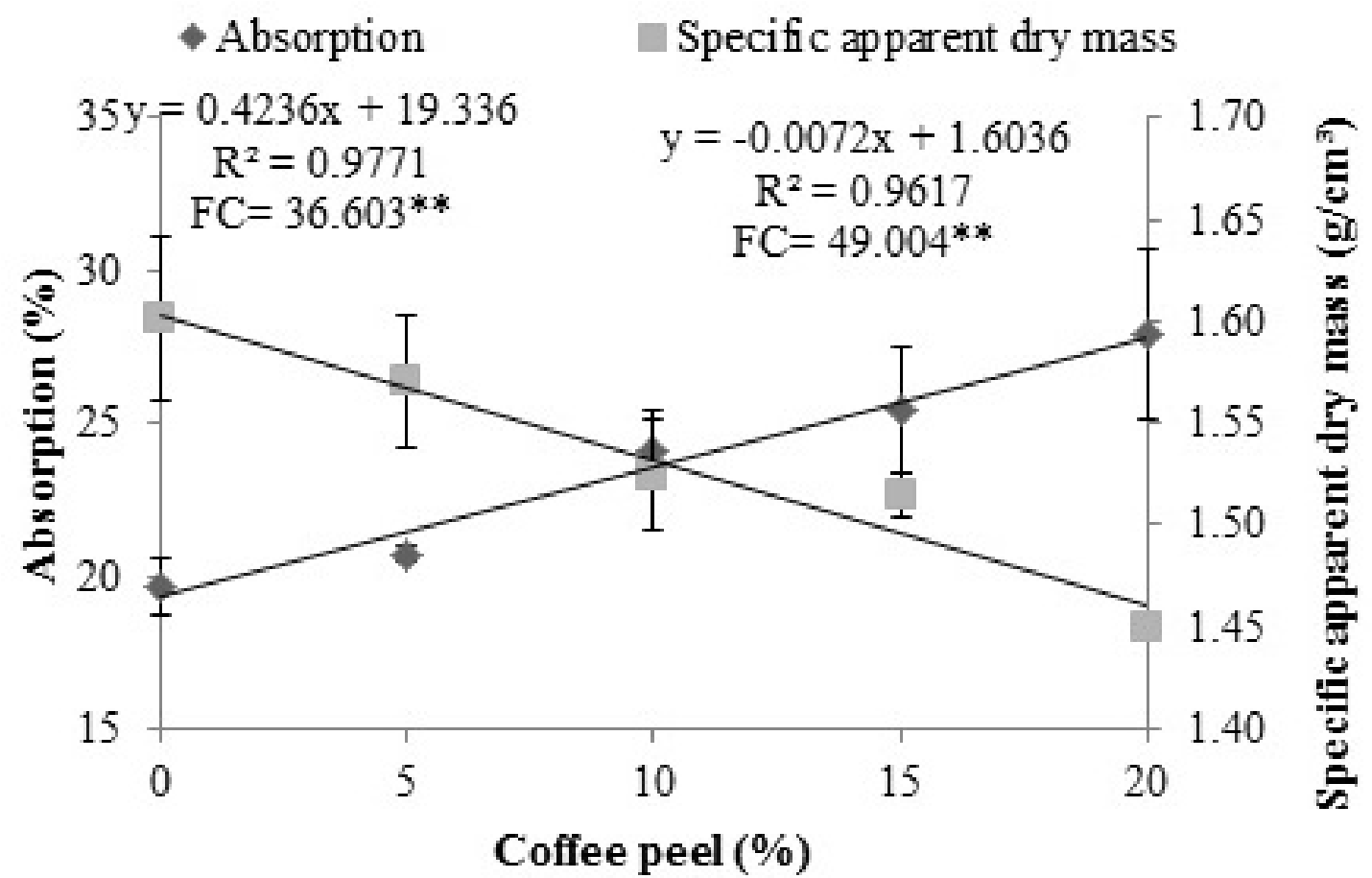

** Significant regression analysis at the level of $5 \%$.

FIGURE 1- Regression analysis, mean values and respective standard deviation, for the apparent specific dry mass and water absorption, in the different cement substitution levels per coffee peel.

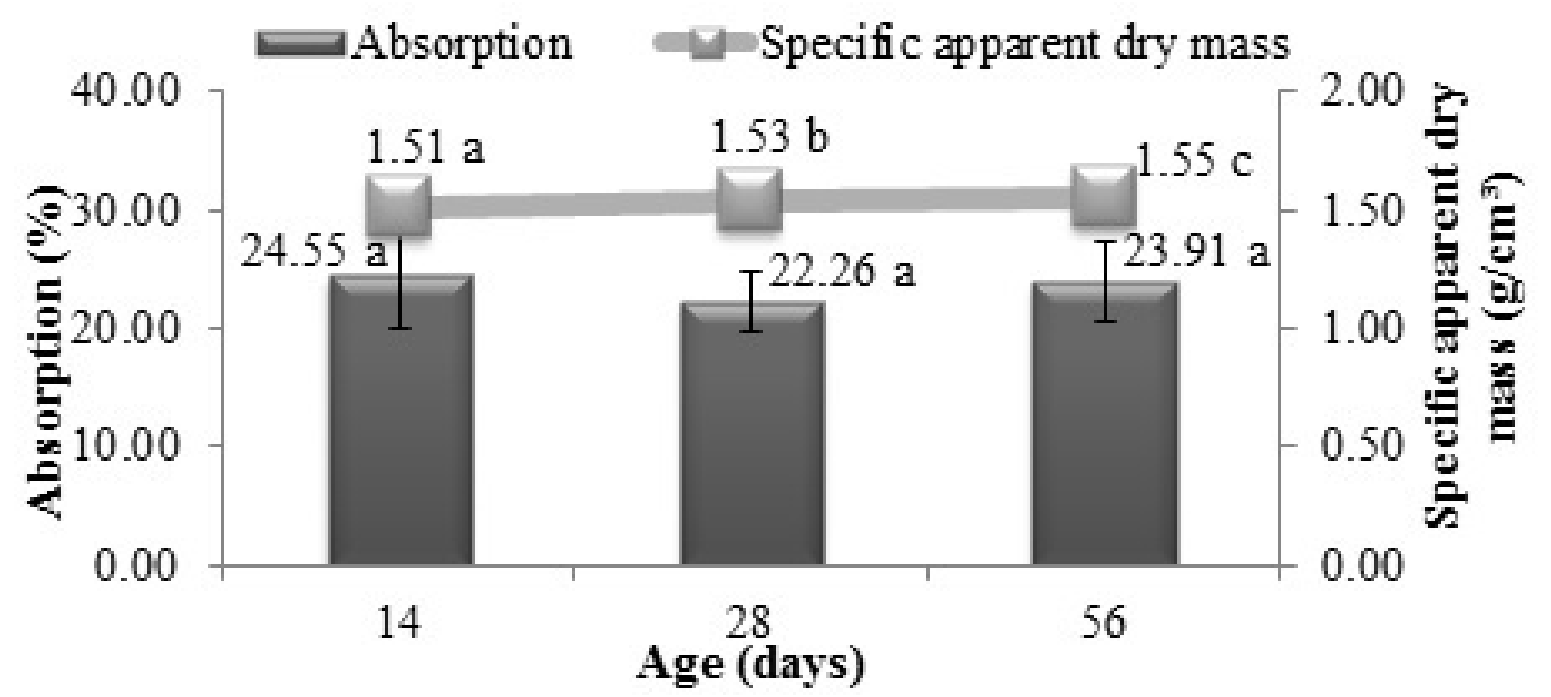

FIGURE 2 - Average values and standard deviation, for the apparent specific dry mass and water absorption, according to the evaluation age of the bricks. 
It should be pointed out that the value of the specific dry mass was higher, according to the advancement in the evaluation age, this behavior may be associated to the cement hydration process, since the empty spaces occupied, initially by water, are gradually filled by the products hydration, resulting in the material densification over time (TAYLOR, 1998).

However, it is observed that the increase in the density of the material with the advancement of the age was not enough to promote the reduction of the absorbed water content, once the treatments presented statistically equal values for the variable water absorption.

Regarding the water absorption, the values reached in this work were above that determined by the NBR 8492 (ABNT, 2012b), which establishes the average limit value for water absorption equal to $20 \%$. Thus, regardless of age, only the treatment with $0 \%$ of coffee peel falls within the normative requirement.

\section{Compressive strength}

Based on the statistical analysis, it was verified that the type of treatment, that is, the percentage of peel, used in partial replacement to the cement, was significant, as well as its interaction with the age evaluation factor. Table 7 shows the mean values found with their respective standard deviation, as well as the result of the statistical analysis for the variable resistance to compression.

When comparing the treatments T0 $(0 \%$ of coffee peel) and T4 (20\% of coffee peel in relation to the cement), a decrease in the resistance of approximately, $52 \%$ at 14 days, $73 \%$ at 28 days e $72 \%$ at 56 days, was observed. Only the T0 treatment ( $0 \%$ of coffee peel) evaluated at 56 days of age, was able to reach the minimum resistance of $2.0 \mathrm{MPa}$, requested by the norm NBR 8491 (ABNT, 2012a), which indicates that other factors interfered in the gain of the material.

The degree of compaction obtained was lower than $95 \%$, indicating that the specific apparent dry mass reached after the production process was significantly lower than that obtained in the compaction essay. The lower the value of the specific dry mass, the greater the presence of voids in the material, which interferes negatively in the soil-binder system, leading to lower resistance values.

The presence of chemical compounds from the vegetal residue, such as extractives, lignins, hemicelluloses, among others; significantly interfere in the hydration cement reaction. Sedan et al. (2008), when evaluating the chemical compatibility between hemp fibers and cement, found that the incorporation of the fibers caused a delay in the initial handle of the cement. The authors also observed the presence of $\mathrm{OH}^{-}$ generated ions from the solubilization of pectin present in the fibers. These ions reacted with calcium present in the cement, forming crystals of $\mathrm{Ca}(\mathrm{OH})_{2}$. Thus, the silicon calcium reactions were impaired, hindering the calcium silicate $(\mathrm{C}-\mathrm{S}-\mathrm{H})$ formation, main product of the cement hydration and responsible for the composite strength.

Despite the fact that the used particles in the study have undergone a washing process in lime solution, and the amount of extractives and lignin present in the waste has considerably decreased and, even so, the presence of chemical compounds, even in reduced amounts, may have negatively influenced the cement hydration reaction, which may have contributed to the low values of compressive strength achieved in this work.

Regarding the age of evaluation of the bricks, from the data contained in Table 6, it is verified that, for the control treatment, the compressive strength was higher, according to the advance in the age of the specimens. A resistance gain of $13.54 \%$ was observed from 14 to 28 days and $44 \%$ from 28 to 56 days. This resistance gain is related to the pores filling by the components formed, mainly, by the hydration of the dicalcium silicates $\left(\mathrm{C}_{2} \mathrm{~S}\right)$ and $\left(\mathrm{C}_{3} \mathrm{~S}\right)$, which are responsible for the resistance growth over time.

For a percentage of 5\% of coffee peel, all ages were statistically the same, indicating, once again, that the vegetal residue affected the cement hydration process, preventing the resistance gain as the passing of years.

The behavior, verified for percentages of cement substitution per peel of $10 \%$ and $15 \%$, was similar. For both, no significant differences were found at the ages of 14 and 28 days, while the evaluated bricks at 56 days had significantly lower averages. For the incorporation content equal to $20 \%$, the lowest resistance value was found at 28 days, which presented a statistically different mean of the ages of 14 and 56 days, which were the same as each other. The reduction of the resistance at 56 days for the percentages of $10 \%$ and $15 \%$ may be related to the alkaline attack suffered by the plant particles, which mainly degrades the lignin present in the particles, promoting the separation of cellulose fibrils (AGOPYAN et al., 2005). 
TABLE 7 - Mean values with their respective standard deviations and mean test, for the compressive strength, in MPa.

\begin{tabular}{cccccc}
\hline \multirow{2}{*}{ Age (days) } & \multicolumn{5}{c}{ Percentages of coffee peels } \\
\cline { 2 - 6 } & $0 \%$ & $5 \%$ & $10 \%$ & $15 \%$ & $20 \%$ \\
\hline 14 & $1.32 \pm 0.13 \mathrm{Aa}$ & $1.42 \pm 0.09 \mathrm{Aa}$ & $1.15 \pm 0.04 \mathrm{Ba}$ & $0.75 \pm 0.07 \mathrm{Ca}$ & $0.68 \pm 0.01 \mathrm{Ca}$ \\
28 & $1.50 \pm 0.11 \mathrm{Ab}$ & $1.37 \pm 0.15 \mathrm{Aa}$ & $1.18 \pm 0.06 \mathrm{Ba}$ & $0.73 \pm 0.07 \mathrm{Ca}$ & $0.41 \pm 0.03 \mathrm{Db}$ \\
56 & $2.16 \pm 0.27 \mathrm{Ac}$ & $1.32 \pm 0.16 \mathrm{Ba}$ & $0.91 \pm 0.09 \mathrm{Cb}$ & $0.51 \pm 0.09 \mathrm{Db}$ & $0.60 \pm 0.03 \mathrm{Da}$ \\
\hline
\end{tabular}

Note: Mean values followed by a same capital letter, on the line, belong to the same cluster by the Scott-Knott test at $5 \%$ significance, relative to the age of evaluation.

Mean values followed by a same lowercase letters in the same column belong to the same cluster by Scott-Knott test at $5 \%$ significance, relative to the age of evaluation.

Although the average values of bricks compressive strength made with vegetal residue were lower than $2 \mathrm{MPa}$, required by NBR 8491 (ABNT, 2012a), bricks produced with up to $10 \%$ of coffee peels in substitution for cement, could be used in constructions with a rustic style, only as sealing masonry without any type of structural function.

\section{Thermal Properties}

The thermal conductivity was calculated considering the radiation emitted by the heat source, obtained with the aid of a radiation measuring device, specimens thickness measurements, as well as temperature variation, calculated from the last thirty measurements recorded by the thermocouples at the base and at the top of the bricks. The results are shown in Table 8 .

It is observed that the temperature variations, for the percentages of $0 \%$ and $5 \%$, presented statistically the same averages. However, these treatments were statistically different from the treatments with the percentages of $10 \%, 15 \%$ and $20 \%$, which obtained statistical equality and the highest of temperature variations. Although the temperature variation increased significantly, according to the insertion of particles of coffee peel in the bricks, it is perceived that it was not sufficient to cause a reduction in the thermal conductivity result, since, for all treatments evaluated the value obtained was equal to 0.20 $\mathrm{W} / \mathrm{m}^{\circ} \mathrm{C}$. The other data of the thermophysical properties of the soil-cement bricks are presented in Table 9.
The NBR 15220-2 (ABNT, 2005b) establishes values for the thermal conductivity of ceramic materials produced with clay, such as bricks and tiles ranging from 0.70 to $1.05 \mathrm{~W} / \mathrm{m} . \mathrm{K}$, for materials with specific mass of 1000 to 2000 $\mathrm{kg} / \mathrm{m}^{3}$, respectively. The bricks developed in this study had values of specific mass, ranging from 1480 to $1816.67 \mathrm{~kg} / \mathrm{m}^{3}$, within the norm, but the thermal conductivities achieved were lower than the normative values. From the point of view of thermal comfort, this reduction is even more favorable, considering that buildings constructed with materials with lower thermal conductivity values imply in milder temperatures inside the environments.

By the values obtained for thermal transmittance and solar gain factor, it is verified that they fit in the determinations of the NBR 152203 (ABNT, 2005c) for external wall-type fences, which require that the thermal transmittance be less than $3 \mathrm{~W} / \mathrm{m}^{2} . \mathrm{K}$ and the lowest solar gain factor equal to $5.0 \%$. This type of fence is recommended for bioclimatic zones 1 e 2 . These zones correspond to parts of the South and Southeast regions of the country and some cities belonging to bioclimatic zoning 1 are: Curitiba-PR, Campos do Jordão-SP, Poços de Caldas-MG, São Joaquim-SC, Caxias do Sul- RS. For bioclimatic zoning 2, we have the following cities: Pelotas-RS, Piracicaba-SP, Ponta Grossa-PR, São João Del Rei-MG, Nova Friburgo-RJ and Laguna-SC. 
TABLE 8 - Temperature gradients of each treatment.

\begin{tabular}{ccccc}
\hline \% Coffee peel & $\begin{array}{c}\Delta \mathbf{T} \\
(\mathrm{K})\end{array}$ & $\begin{array}{c}\text { Thickness } \\
(\mathrm{m})\end{array}$ & Radiation $\left(\mathrm{W} / \mathrm{m}^{2}\right)$ & Thermal Conductivity $(\mathrm{W} / \mathrm{m} . \mathrm{K})$ \\
\hline 0 & $17.25 \pm 1.20 \mathrm{a}$ & 0.1027 & 570 & 0.20 \\
5 & $16.64 \pm 0.45 \mathrm{a}$ & 0.1026 & 570 & 0.20 \\
10 & $20.94 \pm 0.35 \mathrm{~b}$ & 0.1028 & 570 & 0.20 \\
15 & $20.80 \pm 0.56 \mathrm{~b}$ & 0.1027 & 570 & 0.20 \\
20 & $20.60 \pm 0.67 \mathrm{~b}$ & 0.1035 & 570 & 0.20 \\
\hline
\end{tabular}

Note: $\Delta \mathrm{T}$ - temperature variation $(\mathrm{K})$.

TABLE 9 - Main thermophysical properties of bricks.

\begin{tabular}{cccccc}
\hline \% Coffee peel & $\boldsymbol{\rho}$ & $\mathbf{K}$ & $\mathbf{R t}$ & $\mathbf{U t}$ & FSe \\
\hline 0 & 1816.67 & 0.20 & 0.51 & 1.95 & 5.06 \\
5 & 1640.00 & 0.20 & 0.51 & 1.95 & 5.07 \\
10 & 1580.00 & 0.20 & 0.51 & 1.95 & 5.06 \\
15 & 1513.33 & 0.20 & 0.51 & 1.95 & 5.06 \\
20 & 1480.00 & 0.20 & 0.52 & 1.93 & 5.02 \\
\hline
\end{tabular}

Note: $\rho$ - apparent specific mass $\left(\mathrm{kg} / \mathrm{m}^{3}\right)$; K- thermal conductivity $(\mathrm{W} / \mathrm{m} . \mathrm{K})$; Rt- thermal resistance $(\mathrm{m} . \mathrm{K} / \mathrm{W})$; UtThermal transmittance (W/m.K); FSe- solar gain factor (\%).

\section{CONCLUSIONS}

The partial replacement of cement by coffee peels in the soil-cement mix for the manufacture of bricks had a direct impact on the physical, mechanical and thermal properties of the material. The increase in the particle content promoted the fall, in the specific dry bulk density and compressive strength, as well as an increase in the water absorption. The increase in the age of the bricks had a significant effect on the mechanical performance, observing a decrease in the strength achieved, from levels above $10 \%$.

The thermal conductivity value presented by all treatments bricks was equal to $0.20 \mathrm{~kJ} /$ W.m, quite below that that one determined in the NBR 15220, for ceramic materials produced with soil with densities correlated to the bricks densities manufactured in the study, evidencing the potential use of the material in improving the thermal comfort of buildings.

Although the resistance values obtained for the bricks with percentage of coffee husks inserted in their composition do not reach the minimum normative values, the possibility of using them in simpler constructions, such as masonry of fence, should not be emphasized. Therefore, it is essential that new studies should be carried out.

\section{REFERENCES}

AGOPYAN, V. et al. Developments on vegetable fibre-cement based materials in São Paulo, Brazil: An overview. Cement \& Concrete Composites, 27(5):527-536, 2005.

ASASUTJARIT, C. et al. Development of coconut coirbased lightweight cement board. Construction and Building Materials, 21(2):277-288, 2007.

ASHOUR, T.; KORJENIC, A.; KORJENIC, S. Thermal conductivity of unfired earth bricks reinforced by agricultural wastes with cement and gypsum. Energy and Buildings, 104(1):139-146, 2015.

ASSOCIAÇÃO BRASILEIRA DE CIMENTO PORTLAND. Dosagem das misturas de solocimento: normas de dosagem e métodos de ensaio. São Paulo: ABCP, 1986. 51 p. ET-35.

ASSOCIAÇÃO BRASILEIRA DE CIMENTO PORTLAND. Fabricação de tijolos de solo-cimento com a utilização de prensas manuais. São Paulo: ABCP, 2000. 16 p.

ASSOCIAÇÃO BRASILEIRA DE NORMAS TÉCNICAS. NBR 6457: solo: determinação do teor de umidade do solo. Rio de Janeiro: ABNT, 2016a. 8 p. 
ASSOCIAÇÃO BRASILEIRA DE NORMAS TÉCNICAS. NBR 6459: solo: determinação do limite de liquidez. Rio de Janeiro: ABNT, 2016b. 5 p.

ASSOCIAÇÃO BRASILEIRA DE NORMAS TÉCNICAS. NBR 6508: grãos de solos que passam na peneira de 4,8 mm: determinação da massa específica. Rio de Janeiro: ABNT, 1984a. 8 p.

ASSOCIAÇÃO BRASILEIRA DE NORMAS TÉCNICAS. NBR 7180: solo: determinação do limite de plasticidade. Rio de Janeiro: ABNT, 2016c. 3 p.

ASSOCIAÇÃO BRASILEIRA DE NORMAS TÉCNICAS. NBR 7181: solo: análise granulométrica. Rio de Janeiro: ABNT, 1984b. 12 p.

ASSOCIAÇÃO BRASILEIRA DE NORMAS TÉCNICAS. NBR 7182: solo: ensaio de compactação. Rio de Janeiro: ABNT, 1986. 9 p.

ASSOCIAÇÃO BRASILEIRA DE NORMAS TÉCNICAS. NBR 7989: pasta celulósica e madeira: determinação de lignina insolúvel em ácido. Rio de Janeiro: ABNT, 2010a. 6 p.

ASSOCIAÇÃO BRASILEIRA DE NORMAS TÉCNICAS. NBR 8491: tijolo de solo-cimento: requisitos. Rio de Janeiro: ABNT, 2012a. 5 p.

ASSOCIAÇÃO BRASILEIRA DE NORMAS TÉCNICAS. NBR 8492: tijolo de solo-cimento: análise dimensional, determinação da resistência à compressão e da absorção da água: método de Ensaio. Rio de Janeiro: ABNT, 2012b. 4 p.

ASSOCIAÇÃO BRASILEIRA DE NORMAS TÉCNICAS. NBR 10833: fabricação de tijolo e bloco de solo-cimento com a utilização de prensa manual ou hidráulica: procedimento. Rio de Janeiro: ABNT, 2012c. 3 p.

ASSOCIAÇÃO BRASILEIRA DE NORMAS TÉCNICAS. NBR 13999: papel cartão, pasta celulósica e madeira: determinação do resíduo (cinza) após incineração a $525^{\circ} \mathrm{C}$. Rio de Janeiro: ABNT, 2003. 5 p.

ASSOCIAÇÃO BRASILEIRA DE NORMAS TÉCNICAS. NBR 14853: determinação do material solúvel em etanol-tolueno e em diclorometano e em acetona. Rio de Janeiro: ABNT, 2010b. 3 p.

ASSOCIACAO BRASILEIRA DE NORMAS TECNICAS. NBR 15220: desempenho térmico de edificações: parte 1 , definições, símbolos e unidades. Rio de Janeiro: ABNT, 2005a. 8 p.
ASSOCIACAO BRASILEIRA DE NORMAS TECNICAS. NBR 15220: desempenho térmico de edificações: parte 2 , método de cálculo de transmitância térmica, da capacidade térmica, do atraso térmico e do fator solar de elementos e componentes de edificações. Rio de Janeiro: ABNT, 2005b. 34 p.

ASSOCIAÇÃO BRASILEIRA DE NORMAS TÉCNICAS. NBR 15220: desempenho térmico de edificações: parte 3 , zoneamento bioclimático brasileiro e diretrizes construtivas para habitações unifamiliares de interesse social. Rio de Janeiro: ABNT, 2005c. 30 p.

BILBA, K.; ARSENE, M. A.; OUENSANGA, A. Study of banana and coconut fibers: botanical composition, thermal degradation and textural observations. Bioresource Technology, 98(1):58-68, 2007.

CENTRO DE PESQUISAS E DESENVOLVIMENTO - CEPED. Manual de construção com solo-cimento. Camaçari: CEPED, 1999. 116 p.

CHAIB, H.; KRIKER, A.; MEKEHERMECHE, A. Thermal study of earth bricks reinforced by date palm fibers. Energy Procedia, 74:919-925, 2015.

Doukas, H. et al. Renewable energy sources and rationale use of energy development in the countries of GCC: Myth or reality. Renewable Energy, 31(6):755770, 2006.

FRYBORT, S. et al. Cement bonded composites: a mechanical review. Bioresources, 3(2):602-626, 2008.

HIGHWAY RESEARCH BOARD - HRB. Soil stabilization with Portland Cement. Washington: HRB, 1961. 212 p. Bulletin 292.

INSTITUTO DE LA CONSTRUCCIÓN Y GERENCIA. NTE E.080: regulamento. Lima: Nacional Construcciones, 2000. $17 \mathrm{p}$.

IWAKIRI, S.; PRATA, J. G. Utilização da madeira de Eucalyptus grandis e Eucalyptus dunnii na produção de painéis cimento-madeira. Cerne, 14(1):68-74, 2008.

MILANI, A. P. da S.; FREIRE, W. J. Características físicas e mecânicas de misturas de solo, cimento e casca de arroz. Engenharia Agrícola, 26(1):1-10, 2006.

RODRIGUES, L. P.; HOLANDA, J. N. F. Recycling of Water Treatment Plant Waste for Production of SoilCement Bricks. Procedia Materials Science, 8:197-202, 2015. 
SCOTT, A. J.; KNOTT, M. A. Cluster analysis methods four grouping, means in the analysis of variance. Biometrics, 30(3):507-512, 1974.

SEDAN, D. et al. Mechanical properties of hemp fibre reinforced cement: Influence of the fibre/matrix interaction. Journal of Europe Ceramic Society, 28(1):183-192, 2008.

SEGANTINI, A. A.; WADA, H. P. Estudo de dosagem de tijolos de solo-cimento com adição de resíduos de construção e demolição. Acta Scientarium Technology, 33(2):179-183, 2011.

SERRANO, J. S.; CASTRO, J. V. Materiales de construcción com propiedades aislantes a base de cascara de arroz. Informes de la Construcción, 37(372):53-64, 1985.

SUDIN, R.; SWANY, N. Bamboo and wood fibre cement composites for sustainable infrastructure regeneration. Journal Material Science, 41(21):69176924, 2006.
SUTAS, J.; MANA, A.; PITAK, L. Effect of rice husk and rice husk ash to properties of bricks. Procedia Engineering, 32:1061-1067, 2012.

TAYLOR, H. F. W. Cement chemistry. 2. ed. London: T. Telford, 1998. 459 p.

VAICKELIONIS, G.; VAICKELIONIENE, R. I. T. A. Cement hydration in the presence of wood extractives and pozzolan mineral additives. Journal Ceramics Silikaty, 50(2):115-122, 2006.

VALE, A. T. et al. Caracterização energética e rendimento de carbonização e resíduos de grãos de café (Coffea arabica) e madeira (Cedrelinga catenaeformis). Revista Cerne, 13(4):416-420, 2007.

WEATHERWAX, R. C.; TARKOW, H. Effect of wood on setting of Portland cement. Forest Product Journal, 14:567-570, 1964.

ZAK, P. et al. The influence of natural reinforcement fibers, gypsum and cement on compressive strength of earth bricks materials. Construction and Building Materials, 106(1):179-188, 2016. 